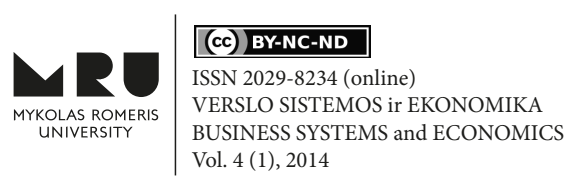

\title{
KOMPLEKSINIS INVESTICINIŲ FONDŲ VEIKLOS VERTINIMAS
}

\author{
Daiva JUREVIČIENE \\ Mykolo Romerio universitetas \\ Ateities g. 20, LT-08303 Vilnius, Lietuva \\ Elektroninis paštas: daiva.jureviciene@mruni.eu \\ Gitana BAPKAUSKAITE் \\ Mykolo Romerio universitetas \\ Ateities g. 20, LT-08303 Vilnius, Lietuva \\ Elektroninis paštas: g.bapkauskaitėgmail.com \\ doi:10.13165/VSE-14-4-1-06
}

Santrauka. Straipsnyje analizuojami investicinių fondų veiklos vertinimo metodai, grąžos ir rizikos rodikliai. Remiantis metinėmis Lietuvoje veikiančių investicinių fondų finansinèmis ataskaitomis apskaičiuojami rodikliai ir, atsižvelgiant ị ekspertų nustatytų kriterijų ir jiems priskirtų reikšmingumo svorių vertinimus, sudaromas modelis, padedantis ịvertinti kiekvieno investicinio fondo finansinę būklę atskirai. Pritaikius daugiakriterinị SAW vertinimo metodą atliktas visapusiškas Lietuvoje veikiančių didžiausių investicinių fondų 2008-2012 m. veiklos vertinimas pagal valdomo turto dydị ir dalyvių skaičių.

Reikšminiai žodžiai: investicinis fondas, grąža, rizika, SAW metodas, ekspertų vertinimas, diversifikacija.

JEL klasifikacija: G23.

\section{Ivadas}

Investicijos igauna vis didesnę reikšmę šiandieniniame pasaulyje, o globalizacijos sąlygos suteikia investuotojams didžiulę pasirinkimo laisvę, kur investuoti savo turimas lèšas. Kadangi finansinių priemonių spektras labai platus, yra daugybė investavimo būdų, tačiau pasaulyje, ypatingai JAV ir Vakarų Europoje, labiausiai paplitusi investicinė priemonè investiciniai fondai. Savo ruožtu tai pati populiariausia investavimo priemonè tarp tų investuotojų, kurie investicinius fondus renkasi dèl likvidumo - galimybès greitai ir lengvai atgauti investuotus pinigus, diversifikacijos - galimybès paskirstyti riziką tarp investicinių priemonių ir profesionalaus valdymo. Tai viena iš pagrindinių priežasčių, lemiančių investuotojų pasirinkimą, nes portfelị valdo kompetentingas asmuo, kuris atsakingas už fondo veiklą ir tolesnius fondo rezultatus. Fondo pagrindinis tikslas - veikti taip, kad investuotojas gautų maksimalų pelną su tam tikra prisiimta rizika. 
Taigi, investicinio fondo veikla aktuali ne tik investuotojams, bet ir fondo valdytojams, kurie turi užtikrinti gerus jų veiklos rezultatus ateityje, siekiant palaikyti jų finansinị stabilumą ir augimą konkurentų atžvilgiu. Tiek užsienio, tiek lietuvių autoriai mokslinèje literatūroje nagrinejja pelningumo ir rizikos rodiklius, kurie padeda įvertinti fondo veiklą ir valdytojo kompetenciją (Barras et al., 2010; Zhao and Shi, 2009; Thaou, 2008; Artikis, 2003; Stankevičienė ir Bernatavičienè, 2012; Gavrilova, 2012). Tačiau kiekvienas rodiklis turi tam tikrų trūkumų ir atskirai neįvertina fondo rezultatų pokyčių, todèl šiame tyrime atliekamas išsamus investicijų veiklos vertinimas, taikant vieną iš daugiakriterinio vertinimo metodų, kriterijų reikšmių sandaugos ir sumavimo - SAW (angl. Simple Additive Weighting) metodą. Daugiakriterinio vertinimo metodai išsiskiria tuo, kad remiamasi kvalifikuotų specialistų nuomone. Todèl tyrime buvo naudota ekspertų apklausa (forma - elektroninė anketa), kuri padejo ne tik nustatyti tinkamus fondų vertinimo rodiklius, bet ir nustatyti jų reikšmingumą. Straipsnio tikslas - įvertinti pasirinktų Lietuvos investicinių fondų veiklą, taikant kriterijų reikšmių sandaugos ir sumavimo metodą. Tyrimo objektas - pasirinkti Lietuvos investiciniai fondai. Tyrimo metodai - mokslinès literatūros, statistinių duomenų analizè, ekspertų apklausa, daugiakriterinio kriterijų reikšmių sandaugos ir sumavimo (SAW) vertinimo metodo taikymas.

\section{Investicinių fondų veiklos vertinimo metodų apžvalga}

Investicinių fondų veiklos vertinimas plačiai aptarinėjamas ir vertinamas JAV. Kaip jau žinoma, Jungtinių Valstijų investicinių fondų rinka pati populiariausia ir labiausiai išvystyta, todèl ir patys pirmieji metodai atsirado būtent šioje šalyje. Investicinio fondo veiklos sèkmè priklauso tiek nuo ekonominių, tiek nuo politinių veiksnių. Tačiau pagrindiniai veiksniai, lemiantys gerus fondo rezultatus, yra fondo valdymas ir tinkamos strategijos sudarymas. Jau penktajame dešimtmetyje pradejo kurtis tam tikri modeliai, padedantys išanalizuoti investicinių fondų veiklą. Vienas jų - portfelio formavimas. Vertybinių popierių portfelio formavimo teorija nagrinejja, kaip asmenys, formuojantys savo portfelį iš ịvairių vertybinių popierių, gali pasiekti didžiausią grąžą, esant tam tikroms rizikos sąlygoms. Taigi, pirmąji modelį, kuris atsižvelgè i riziką ir pelną, sudarant investicinị portfelį, $1952 \mathrm{~m}$. pateikẻ amerikiečių ekonomistas Harry M. Markowitz (1 pav.). Jis pasiūle portfeliui sudaryti naudoti tokius rodiklius kaip: duodamą vertybinių popierių vidutinị pelną, koreliaciją tarp fondą sudarančių vertybinių popierių ir standartinị nuokrypị. Ši teorija leido atsirinkti pačius svarbiausius rodiklius optimaliam portfeliui sudaryti (Sakalauskas, 2003). Ypatingai svarbus Markowitz modeliui apskaičiuoti rodiklis - standartinis nuokrypis, kuris parodo rizikos laipsni - kuo didesnis standartinis nuokrypis, tuo rizika didesnè, ir atvirkščiai. Investuotojui pasirinkti jam pačiam tinkamiausią variantą, sudarant investicini portfelį, leidžia efektyvumo kreivė, kurią pirmasis sudare taip pat H. M. Markowitz. Šis modelis nenustato vieno optimalaus portfelio, jis tik apibrèžia ribą, kurioje visi variantai yra optimalūs. Efektyvumo linija apibrèžia portfelius su fiksuota rizika, esant maksimaliam pelnui, arba atvirkščiai, fiksuotam pelnui, esant mažiausiai rizikai (Markowitz, 1999). 
1 pav. Markowitz modelis

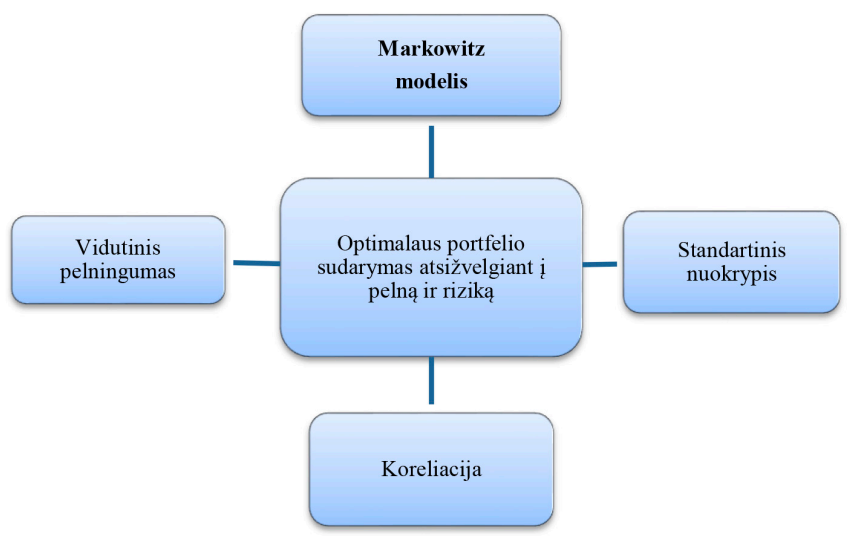

Šaltinis: Valentinavičius (2010)

Todèl kiekvienas investuotojas gali susidaryti portfeli pagal sau tinkanti rizikos ir pelno santyki, remdamasis efektyvumo kreive (Sakalauskas, 2003). Kaip jau minèta, H. M. Markowitz modelio teorija vaizduoja pelningiausią portfeli, esant tam tikrai rizikai, tačiau remiasi jau žinomais rezultatais, todèl, jei portfelis šiuo metu yra efektyvus, nereiškia, kad jis bus toks ir rytoj. Taigi, vertinant portfelio veiklą, patartina naudoti bent trejų metų duomenis. Galima daryti išvadą, kad remiantis šia teorija, reikètų atsižvelgti ir i portfelio rezultatus lemiančius veiksnius, tokius kaip įmonių veiklą, rinkos dalyvių aktyvumą, investavimo aplinką ir ị kitas priežastis, kurios lemia finansinių priemonių kainų pokyčius (Valentinavičius, 2010).

H. M. Markiwitz teorija padejjo pagrindą tolesniam šios teorijos plètojimui tokiems mokslininkams, kaip William F. Sharpe 1964 m., Jack L. Treynor 1965 m. ir Jan Mossino 1996 m. (Markowitz, 1999). Vèliau šis modelis buvo išplètotas kaip kapitalo aktyvų ikainojimo modelis (angl. Capital asset pricing model - CAMP), kuris naudojamas sisteminei rizikai išmatuoti. Sisteminès rizikos pasikeitimus lemia bendrojo vidaus produkto (toliau - BVP), infliacijos, palūkanų normos ir kt. makroekonominių rodiklių pasikeitimai. CAPM modelis teoriškai paaiškina numatomos grąžos ir aktyvų kainos santykio prognozes (Valentinavičius, 2010). Ši teorija svarbi dviem aspektais:

- pirmiausia, padeda išsiaiškinti, ar investicijų grąža yra reali lyginant ją su rizika, ir

- antra, galima išanalizuoti akcijų, kurių dar nèra rinkoje, kainos prognozę, remiantis prielaidomis ir spejjimais.

Mokslininkų Sakalausko (2003), Lileikienès ir Daugintytès (2009), Coperland and Weston (1992) nuomone, CAPM modelis yra ganètinai paprastas skaičiuojant portfelio grąžą, tačiau norint realių rezultatų taikant ši metodą, reikia, kad ir fondus sudarančios finansinès priemonès turètų vienodas strategijas, tik tuo atveju bus gaunami tinkami rezultatai (Valentinavičius, 2010).

Kadangi CAPM modelio naudojimas portfelio sudarymui ịvertinti nèra labai tikslus dèl pasirinktų indeksų, kaip alternatyva šiam modeliui buvo pradètas analizuoti arbitražo ịkainojimo modelis (angl. Arbitrage pricing theory - APT) (Basu and Chawla, 2012). 
1976 m. Stephen Rosso pasiūlè modelį, kuris teigia, kad kiekvienas fizinis ar juridinis asmuo nori padidinti savo portfelio grąžą, nedidindamas rizikos (Valentinavičius, 2010). S. Rosso modelis, kaip ir CAPM, teigia, kad vertybinių popierių pelningumą lemia sisteminè rizika, tačiau šioje situacijoje, skaičiuojant portfelio pelningumą, nereikia vienodų nustatymų kaip CAPM modelyje.

Remdamasis jau minètais metodais 1965 m. J. L. Treynor pristate pirmąji koeficientą, kuris apėmė pagrindinius du veiksnius - riziką ir pelningumą. Jis išskyrè du skirtingus rizikos aspektus: riziką, kuri kyla iš konkretaus vertybinių popierių svyravimo portfelyje, ir riziką, kuri kyla iš bendros rinkos svyravimų (Dzikevičius, 2004). Vèliau šị koeficientą išplètojo W. F. Sharpe ir pavadino ji atlygio už nepastovumą rodikliu. Tai rodiklis, rodantis, koks vienam rizikos vienetui atiteks rizikos premijos pelningumas. Skirtumas tarp šių dviejų koeficientų yra tas, kad J. L. Treynor, skaičiuodamas riziką, naudoja sisteminę riziką ( $\beta$ ), kuri nieko nepasako apie portfelio diversifikavimą, o J. L. Sharpe siekia ịvertinti visą fondo riziką, naudodamas pelningumo standartinị kvadratinị nuokrypị.

Atsižvelgiant ị visus paminètus portfelio sudarymo metodus reikètų paminèti, kad jie padeda fondo valdytojams valdyti portfelius. Kiekvienas investuotojas gali prisitaikyti fondo riziką ir pelningumą atitinkamai savo poreikiams. Šiomis dienomis vis dažniau grị̌zama prie teorinių metodų, kuriuos taiko fondų valdytojai, sudarydami investicinius portfelius, tačiau reiktų nepamiršti, kad investicinių fondų veiklą lemia ne tik ekonominiai, bet ir politiniai veiksniai, todèl daug kas priklauso nuo sẻkmès ir fondų valdytojų sugebejjimų.

Dar vienas investicinių fondų veiklos vertinimo metodų yra fondų valdytojų veiklos analizè. Vertinant ši aspektą yra išskiriamos kelios nuomonès, Anot vienų mokslininkų, fondų valdytojų veikla neturi įtakos investicinių fondų rinkai, tai įrodė savo tyrimais Elton, et al. (1993), Brown and Geotzmann (1995). Priešingą požiūrị pateikè mokslininkai Bello and Janjingas (1997). Kiti, Grinblatt and Titman (1994) ištyrè ir pateikè tarpinị variantą, kad vis dèlto fondų valdytojai turi įtakos valdant fondų veiklą, bet rinkos nuspèti negali (Stankevičienė ir Gavrilova, 2012). Tačiau šie tyrimai yra preliminarūs, nes taiko skirtingus analizès metodus. Taigi, atsižvelgiant ị minètus tyrimus, tikètina, kad fondų valdytojai turi didelę reikšmę fondo valdymui. Valdytojas formuoja fondo strategijas, struktūrą, sprendžia, kokios investicijų rūšys sudarys portfelį, taip pat remiasi patirtimi ir sėkme, nes ne visada įmanoma nuspèti politinius ir kitus veiksnius, turinčius ịtakos rinkų kainoms. Taip pat labai svarbus aspektas - portfelio diversifikavimas, tinkamai paskirstyti riziką ir gauti numatytąją grąžą. Šie veiksniai lemia investuotojų pasirinkimą, todèl fondo valdytojas privalo turèti pakankamai fondo valdymo kompetencijos, nuo kurios priklauso fondo veikla ir tolesni rezultatai.

Išanalizavus ịvairius metodus, galima teigti, kad iš esmès visi metodai yra panašūs ir siekia vieno pagrindinio tikslo - optimalaus portfelio sudarymo, kurio formavimui didelę ịtaką daro valdytojo kompetencija. Išanalizavus finansinių investicinių fondų veiklos vertinimo metodus, galima pereiti prie kitų svarbių veiksnių, rodiklių, kurie atspindi fondo investicinę veiklą ir valdytojų sugebejjimus tinkamai reaguoti ị kintančią padèti rinkoje.

\section{Pagrindinai investicinių fondų veiklos vertinimo rodikliai}

Aptarus investicinių fondų veiklos vertinimo metodus, tikslinga būtų apžvelgti ir investicinių fondų veiklos ịvertinimo rodiklius. Remiantis Lietuvos Respublikos kolektyvinio investavimo subjektų įstatymu (2012), fondų valdytojai nuo $2008 \mathrm{~m}$. fondų rezultatus turi skelbti viešai, metinėse ataskaitose. Atsižvelgiant ị tai, kad investicinių fondų strategijos yra 
skirtingos, gaunami rezultatai nèra vienodi. Todèl, vertinant investicinių akcijų, obligacijų, mišrių fondų ir kt. fondų veiklą, pirmiausia juos reikètų vertinti pagal keletą pagrindinių rodiklių, kurie atspindi fondų finansinę būklę (Artikis, 2003; Zhao and Shi, 2009).

2 lentelè. Investicinių fondų veiklos vertinimo rodiklių charakteristikos

\begin{tabular}{|c|c|c|c|}
\hline Rodiklis & Formulè & Privalumai & Trūkumai \\
\hline Fondo grąža & $R=\frac{N A V_{1}+D-G}{N A V_{0}}-1$ & $\begin{array}{l}\text { Parodo fondo me- } \\
\text { tinị pelningumą }\end{array}$ & Neịvertina rizikos \\
\hline $\begin{array}{l}\text { Koreliacijos } \\
\text { koeficientas }\end{array}$ & Excel funkcija & \begin{tabular}{|l} 
Ivertina ryši tarp \\
veiksnių
\end{tabular} & Neịvertina rizikos \\
\hline Alfa & $\alpha=R_{i}-\left[R_{f}+\beta_{i M}^{*}\left(R_{M}-R_{f}\right)\right]$ & $\begin{array}{l}\text { Parodo fondo pel- } \\
\text { ningumą ir leidžia } \\
\text { ji palyginti }\end{array}$ & $\begin{array}{l}\text { Orientuotas ị grąžą, } \\
\text { neịvertina rizikos }\end{array}$ \\
\hline Beta & $\beta_{t}=\operatorname{Var}_{t}\left(r_{p, t+1}\right)^{-1} \operatorname{Cov}_{t}\left(r_{p, t+1}, r_{t+1}\right)$ & Ivertina riziką & $\begin{array}{l}\text { Ivertina tik sisteminę } \\
\text { riziką }\end{array}$ \\
\hline $\begin{array}{l}\text { Standartinis } \\
\text { nuokrypis }\end{array}$ & $\sigma=\sqrt{\frac{\sum_{i=1}^{n}\left(r_{i}-\bar{r}\right)^{2}}{n-1}}$ & $\begin{array}{l}\text { Parodo fondo } \\
\text { svyravimus }\end{array}$ & $\begin{array}{l}\text { Skaičiavimas orientuo- } \\
\text { tas ị vidurki, dispersiją, } \\
\text { neịvertina skirtingų } \\
\text { strategijų fondų }\end{array}$ \\
\hline Šarpo & $S_{i}=\frac{r_{i}-r_{F}}{\sigma_{i}}$ & $\begin{array}{l}\text { Leidžia palyginti } \\
\text { skirtingų strategijų } \\
\text { fondus }\end{array}$ & $\begin{array}{l}\text { Skaičiavimas orientuo- } \\
\text { tas ị vidurki, dispersiją }\end{array}$ \\
\hline Treynoro- Blacko & $T B R_{i}=\left(\frac{r_{i}-r_{F}}{\sigma_{i}}\right)^{2}$ & $\begin{array}{l}\text { Leidžia palyginti } \\
\text { skirtingų strategijų } \\
\text { fondus }\end{array}$ & $\begin{array}{l}\text { Keliant kvadratu, gali } \\
\text { būti iškraipomi rezul- } \\
\text { tatai }\end{array}$ \\
\hline
\end{tabular}

Šaltinis: Dzikevičius (2004); Sakalauskas (2003)

Remiantis pateiktais lenteleje rodikliais, tikslinga aptarti fondo grąžos rodikli, kuris padeda investuotojui įvertinti pastarųjų metų fondo veiklos rezultatus. Fondų valdymo įmonès savo metinėse ataskaitose pateikia tris pagrindinius minètus rodiklius, kurie susieti su lyginamaisiais indeksais, t. y. koreliacijos koeficientas, Alfa ir Beta rodikliai.

Koreliacijos koeficientas parodo pasirinkto lyginamojo indekso ir fondo tarpusavio priklausomybę. Plačiąja prasme, koreliacijos koeficientas parodo tam tikrą ryši tarp pasirinktų veiksnių. Kuo koeficiento reikšmè artimesnė 1, tuo ryšys stipresnis. Šiuo atveju fondo ir lyginamojo indekso rezultatai panašesni. Lietuvos fondų valdymo įmonès taiko reikalavimą, kad fondo koreliacijos koeficiento reikšmè neturètų būti mažesnè nei 0,7 (Stankevičienė ir Gavrilova, 2012).

Alfa rodiklis charakterizuoja vertybinių popierių pelningumą (numatomą), kai rinkos pelningumas lygus 0. Jei Alfa rodiklis lygus 0, papildoma grąža gaunama tik iš papildomai prisiimtos rizikos. Šis koeficientas parodo skirtumą tarp investicinio vieneto vertès pasikeitimo ir lyginamojo indekso reikšmès pasikeitimo (Thaou, 2008; Žvirblis ir Rinkevičiūtė, 2012). Paprasčiau tariant, teigiamas Alfa rodiklis parodo, kad investicinis fondas pasieke didesnị pelningumą lyginant su rinkos pelningumo lygiu (Plakys, 2011). Teigiamas Alfa rodiklis parodo gerus fondo valdytojo valdymo rezultatus, o neigiamas Alfa reiškia, kad fondų valdytojas nesugebėjo uždirbti tiek pat, kiek tokios pačios rizikos indeksas. Reikètų 


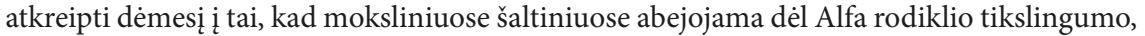
nes dẻl statistinių paklaidų rodiklio gaunama reikšmė mažesnè, nei turètų būti (Grinblatt and Titman, 1994; Nielsen and Vassalou, 2004; Thanou, 2008).

Trečiasis rodiklis, susietas su lyginamuoju indeksu, yra Beta. Beta naudojamas sisteminei rizikai apskaičiuoti, gautas koeficientas parodo fondo vertès vieneto pokyti, pasikeitus lyginamojo indekso reikšmei. Jei Beta yra lygus 1, tai reiškia, kad fondo kintamumas (rizika) yra toks pat kaip ir lyginamojo indekso. Tai reiškia, kad fondo vertès pokytis turi būti toks kaip ir indekso. Kai Beta daugiau už 1, fondas prisiima didesnę riziką, todèl ilguoju laikotarpiu jis turètų uždirbti daugiau. Pavyzdžiui, jei fondo Beta yra 1,05, tai indeksui kylant fondo grąža bus 5 proc. didesnè, o rinkoms krentant - atvirkščiai, 5 proc. mažesnè. Kitaip sakant, Beta rodiklis parodo fondo priklausomybę nuo rinkos svyravimų (Stankevičienė ir Bernatavičienè, 2012). Remiantis užsienio mokslininkų teigimu, Beta rodiklis atskirai neanalizuojamas, tiesiog naudojamas kaip vienas iš regresinès analizès modelio veiksnių (Conover and Friday, 2000; Cuthberston, et al., 2006).

Kitas rodiklis, padedantis apskaičiuoti riziką, yra vidutinis standartinis nuokrypis, kuris parodo, kiek faktinis investicijų pelnas gali skirtis nuo numatomos vidutinės fondo grąžos, bet egzistuoja tam tikra paklaida. Standartinio nuokrypio rodiklis padeda ịvertinti fondo pelningumo nuokrypi nuo vidutinio, t. y. kiek procentų, atitinkamai daugiau ar mažiau už vidutinį savo pelningumą, fondo vertė svyravo per tam tikrą laikotarpi (Stankevičienẻ ir Gavrilova, 2012). Standartinis nuokrypis yra tinkamas pelningumo rizikos matas tik tuo atveju, jei tarpusavyje lyginamos investicijos, kurių numatomas pelningumas yra vienodo dydžio, tuomet pelningumo tikimybè pasiskirsto simetriškai (Lileikienė ir Daugintytė, 2009).

Iki šiol nagrinèti rizikos ir pelningumo rodikliai neparodo tikslių fondo veiklos rezultatų, jei investicinių fondų strategijos yra skirtingos (skiriasi fondų rūšys, grąžos ir pelningumo lygis), todèl, norint ịvertinti skirtingos strategijos portfelį, skaičiuojamas Šarpo (angl. Sharpe) rodiklis. Tai vienas iš riziką ir grąžą susiejančių rodiklių, naudojamas ịvertinti, kaip efektyviai turto grąža kompensuoja investuotojo prisiimtą riziką (Žvirblis ir Rinkevičiūtė, 2012; Stankevičienè ir Gavrilova, 2012).

Šarpo rodiklis padeda nuspręsti, kas lemia investicinių fondų grąžą, - ar profesionalūs fondo valdytojų sprendimai ir strategija, ar prisiimta papildoma rizika. Svarbus aspektas, kuris pažymi rodiklio išskirtinumą, yra tai, kad portfelio grąža bus efektyvi tik tuo atveju, jei Šarpo rodiklis bus didesnis nei kitų fondų, nepaisant to, kad fondo grąža bus didesnè už kitų fondų. Taigi, Šarpo koeficientas leidžia palyginti skirtingų strategijų fondus (Dzikevičius, 2004; Gavrilova, 2011). Norint apskaičiuoti Šarpo rodiklį, rekomenduojamas fondo investavimo laikotarpis turètų būti ne mažesnis nei treji metai, ilguoju laikotarpiu nagrinèjamas fondo veiklos efektyvumas yra tikslesnis.

Dar vienas metodas, taikomas vertinant investicinių fondų veiklą, koreguotą pagal riziką, - tai Treynoro ir Blacko koeficientas, kuris apskaičiuojamas kaip Šarpo rodiklis, tiesiog pakeltas kvadratu.

Apibendrinant mokslinėje literatūroje analizuojamus metodus, galima daryti išvadas, kad, taikant kiekvieną iš minètų metodų, galima apskaičiuoti fondo pelningumą esant tam tikram rizikos laipsniui. Tačiau išnagrinèti rodikliai tik iš dalies leidžia susidaryti bendrą nuomonę apie investicinio fondo veiklą. Kiekvienas analizuotas rodiklis bei metodas turi tam tikrų trūkumų. Jau buvo minèta, kad tokie rodikliai, kaip Alfa, Beta, variacijos koeficientas, labiau orientuoti ị fondo grąžą, todèl ịvertinti portfelio rizikos laipsnio nepadeda, juo labiau palyginti skirtingų strategijų fondus. Anot Stankevičienès ir Bernatavičienès (2012), 
daugumos rodiklių skaičiavimas orientuotas ị vidurkị ir dispersiją (variacijos koeficientas, standartinis nuokrypis, Šarpo, Alfa ir Beta rodikliai, Treynoro ir Blacko koeficientas, taip pat Treynoro, Mazuy modelis). Beta rodiklis remiasi prielaida, kad portfelis yra visiškai diversifikuotas, todèl atsižvelgiama tik ị sisteminę riziką, pamirštant, kad egzistuoja ir nesistemine. Šarpo rodiklis yra daug tikslesnis nei Treinoro ir Balcko koeficientas, nes pastarasis keliamas kvadratu ir rezultatas gali būti iškraipomas, todèl gauti duomenys nebe tokie tikslūs. Kadangi atskirai analizuojami metodai ir rodikliai neatspindi investicinių fondų veiklos, toliau bus analizuojami pagrindiniai grąžos, rizikos rodikliai ir, remiantis metinėmis ataskaitomis, bus taikomas daugiakriterinis investicinių fondų vertinimas, pasitelkiant kriterijų reikšmių ir jų reikšmingumų sandaugų sumavimo (angl. Simple Additive Weighting SAW) metodą.

\section{Investicinių fondų veiklos rezultatų vertinimas, taikant SAW metodą}

Teorinejje dalyje buvo apžvelgiama daugybė rodiklių, padedančių išanalizuoti ir susidaryti bendrą vaizdą apie investicinio fondo veiklą. Tačiau remiantis moksline literatūra (Stankevičienè ir Bernatavičienè, 2012, Sergejeva, 2011 ir kt.) teigtina, kad fondų veiklos vertinimas yra sudètingas procesas tiek ekonominiu, tiek socialiniu požiūriu. Pagrindinių fondų veiklos vertinimo rodiklių palyginimas padeda įvertinti fondo veiklos rezultatus gana abstrakčiai. Todèl tikslinga svarbiausius rodiklius sujungti $\mathfrak{i}$ vieną, kuris atspindètų bendrą portfelio veiklos efektyvumą.

Norint objektyviai įvertinti investicinių fondų veiklą svarbu, kad jų istorinis laikotarpis būtų ne mažesnis nei treji metai. Šiuo atveju buvo pasirinktas penkerių metų 2008-2012 m. laikotarpis. Anot Jasienès ir Kočiūnaites (2007), kuo ilgesnis laikotarpis, tuo tikslesni bei mažiau iškraipomi vidutinio standartinio nuokrypio ir grąžos rezultatai. Pažymėtina, kad 2008 m. ir 2011 m. nagrinėjamų rodiklių rezultatams daug ịtakos turèjo, pasaulinė krizé, kuri sukèlè didelius svyravimus finansų rinkose. Fondai buvo pasirinkti atsižvelgiant i valdomą turtą ir dalyvių skaičių. Didžiausi Lietuvos investiciniai fondai pagal valdomą turtą ir dalyvių skaičių priklauso UAB „SEB investicijų valdymas“, UAB „Finasta Asset Management“, UAB „DNB investicijų valdymas“, UAB „Citadele investicijų valdymas“ bendrovèms. Tačiau ị tyrimą dèl per mažo istorinio laikotarpio nebuvo įtraukta UAB „Finasta Asset Management“ bendrovè.

Analizei pasirinkti rodikliai ir fondai pateikiami 3 lentelèje.

3 lentelè. Investicinių fondų veiklos vertinimo kriterijų reikšmės 2008-2012 m. laikotarpiu

\begin{tabular}{|c|c|c|c|c|c|}
\hline Kriterijus / Fondai & $\begin{array}{c}\text { Citadele } \\
\text { Baltijos jūros } \\
\text { valstybių } \\
\text { akcijų fondas } \\
\end{array}$ & $\begin{array}{c}\text { DNB akcijų } \\
\text { fondų } \\
\text { fondas }\end{array}$ & $\begin{array}{c}\text { SEB aktyviai } \\
\text { valdomas fondų } \\
\text { portfelis } 100\end{array}$ & $\begin{array}{c}\text { DNB } \\
\text { likvidumo } \\
\text { fondas }\end{array}$ & $\begin{array}{l}\text { SEB aktyviai } \\
\text { valdomas } \\
\text { fondu } \\
\text { portfelis } 60 \\
\end{array}$ \\
\hline Fondo turtas, mln. Lt & 11,935 & 9,697 & 85,099 & 35,154 & 115,252 \\
\hline $\begin{array}{l}\text { Fondo investicinių } \\
\text { vienetų skaičius, } \\
\text { tūkst. }\end{array}$ & 103,589 & 10328,256 & 104891,087 & 28,459 & 102978,501 \\
\hline $\begin{array}{l}\text { Valdymo mokes- } \\
\text { čiai, \% }\end{array}$ & 2 & 1,25 & 1,25 & 0,6 & 0,75 \\
\hline Beta rodiklis & 0,9629 & 0,8119 & 0,9174 & 1,4488 & 0,9131 \\
\hline
\end{tabular}




\begin{tabular}{|l|r|r|r|r|r|}
\hline Alfa rodiklis, \% & 10,5595 & 2,9176 & $-1,5216$ & 2,2996 & $-1,4677$ \\
\hline Šarpo rodiklis & $-0,1575$ & $-0,4827$ & $-0,4465$ & $-2,5897$ & $-1,2301$ \\
\hline $\begin{array}{l}\text { Treynoro ir Blacko } \\
\text { koeficientas }\end{array}$ & 0,0248 & 0,2329 & 0,1994 & 6,7065 & 1,5131 \\
\hline $\begin{array}{l}\text { Koreliacijos koefici- } \\
\text { entas }\end{array}$ & 0,95 & 0,93 & 0,99 & 0,30 & 0,99 \\
\hline $\begin{array}{l}\text { Standartinis nuokry- } \\
\text { pis, \% }\end{array}$ & 19,68 & 13,26 & 18,68 & 0,39 & 12,16 \\
\hline $\begin{array}{l}\text { Grynoji investicijų } \\
\text { grąža, \% }\end{array}$ & $-6,25$ & $-1,79$ & $-3,79$ & 3,49 & $-0,81$ \\
\hline $\begin{array}{l}\text { Investicinio vieneto } \\
\text { vertés pokytis, \% }\end{array}$ & 1,4 & $-1,9$ & $-3,84$ & 3,49 & $-0,86$ \\
\hline
\end{tabular}

Šaltinis: sudaryta autorių, remiantis fondų metinėmis veiklos ataskaitomis

Daugiakriterinio vertinimo metodai išsiskiria tuo, kad, atliekant tyrimą, remiasi kvalifikuotų specialistų nuomone, kurie padeda ne tik pasirinkti tyrimo objektui labiausiai ịtakos turinčius veiksnius, bet ir ịvertinti jų reikšmingumą.

Ekspertų tyrime buvo panaudota anoniminė apklausos anketa. I jos klausimus atsakè investicinių bendrovių UAB „Citadele investicijų valdymas“, UAB „SEB investicijų valdymas“, UAB „Finasta investicijų valdymas“, UAB „Orion Asset Management“ kvalifikuoti specialistai. Siekiant tikslingo, išsamaus ir profesionalaus tyrimo specialistams buvo nustatyti kriterijai, kuriais remiantis atrinkti ekspertai. Kriterijai yra svarbi tyrimo dalis, nes nuo valdytojo sugebejimo valdyti fondą priklauso fondų rezultatai.

Pasirinkti keli kriterijai, kuriais remiantis buvo atrinkti tyrime dalyvavę ekspertai:

- Užimamos pareigos (fondo valdytojas, finansų konsultantas, finansų pardavimų konsultantas);

- Eksperto kompetencija (pagal metinius fondo rezultatus, fondo valdymą, eksperto pasiekimus);

- Darbo patirtis (ne mažesnè kaip 3 metai toje pačioje kampanijoje).

Buvo apklausti 6 ekspertai, kurie atsakè ị anketoje pateiktą klausimyną. Apklausa vyko elektronineje erdveje, asmeniniu elektroniniu paštu. Skirtingų bankų pasirinkti ekspertai užtikrino tyrimo pagrịstumą ir įvairiapusę nuomonę.

Pagrindiniai klausimyne nurodyti rodikliai buvo atrinkti pagal kelis kriterijus:

- Pirmasis, remiantis metinemis fondų ataskaitomis;

- Antrasis, remiantis mokslinès literatūros analize;

- Trečiasis, remiantis ekspertų nuomone.

Klausimynas buvo sudaryta pagal Likerto skalę. Likerto skale - tai vienas iš anketos sudarymo segmentų, naudojamų moksliniuose tyrimuose, norint nustatyti pasirinktų (rodiklių, teiginių, veiksnių) svarbumą nuo reikšmingiausio iki nereikšmingiausio. Ekspertai kiekvieną rodiklị ịvertino pagal svarbą intervale nuo 0 iki 1 . Be to, visų pasirinktų rodiklinių reikšmingumo koeficientų bendra suma turi būti lygi vienetui (Pranulis ir Dikčius, 2012). Klausimyną sudaro pagrindiniai rodikliai, kurie padeda įvertinti fondų veiklą, jų rezultatus ir ateities perspektyvas. Standartinis nuokrypis, Beta, Šarpo rodikliai padeda ịvertinti riziką, koreliacijos koeficientas leidžia ịvertinti ryši tarp analizuojamųjų veiksnių, Alfa rodiklis parodo fondo pelningumą, lyginant su rinkos pelningumu. Iš esmės visi rodikliai yra susiję. Vienu ar kitu atžvilgiu visi jie parodo fondo pelningumą esant tam tikrai rizikai. 
Norint toliau taikyti gautus ekspertų vertinimus, prieš tai reikia ịvertinti nuomonių suderinamumą. Rodikliai buvo ranguojami kiekvieno eksperto atžvilgiu, kadangi buvo apklausti šeši ekspertai ( $n>2)$, skaičiuojamas konkordancijos koeficientas pagal formulę (Podvezko ir Ginevičius, 2008a):

$$
\mathrm{W}=12 \mathrm{~S} / \mathrm{r}^{2} \mathrm{~m}\left(\mathrm{~m}^{2}-1\right)
$$

Šio rodiklio gauta reikšmè, kad tyrimas būtų tikslingas, turi svyruoti intervale nuo $0 \mathrm{iki}$ 1. Kuo reikšmė artimesnè vienetui, tuo ekspertų nuomonès labiau suderintos. Apskaičiavus konkordancijos koeficientą gautas rezultatas $(\mathrm{W}=0,865)$ parodo, kad analizė yra tikslinga ir toliau galima tęsti tyrimą.

Ekspertų nustatyti reikšmingumo laipsniai ir gauti svoriai pateikiami 4 lentelèje.

4 lentelè. Ekspertų vertinimo kriterijų svoriai

\begin{tabular}{|l|c|c|c|c|c|c|c|c|}
\hline \multicolumn{1}{|c|}{ Kriterijus } & Citadele & Finasta & SEB & Orion & SEB & SEB & Iš viso & Svoris \\
\hline $\begin{array}{l}\text { Investicinis vieneto vertes } \\
\text { pokytis, \% }\end{array}$ & 0 & 0,05 & 0,15 & 0,2 & 0,2 & 0 & 0,6 & 0,100 \\
\hline Grynoji investiciju grǎža & 0,2 & 0 & 0,05 & 0,02 & 0,25 & 0,1 & 0,62 & 0,103 \\
\hline Standartinis nuokrypis, \% & 0,2 & 0,2 & 0,1 & 0,2 & 0,1 & 0,1 & 0,9 & 0,150 \\
\hline Koreliacijos koeficientas & 0,1 & 0 & 0,05 & 0,1 & 0,15 & 0 & 0,4 & 0,067 \\
\hline Šarpo rodiklis & 0,15 & 0,2 & 0,2 & 0,2 & 0,15 & 0,2 & 1,1 & 0,183 \\
\hline Alfa rodiklis, \% & 0,1 & 0,2 & 0,1 & 0,05 & 0 & 0,1 & 0,55 & 0,092 \\
\hline Beta rodiklis & 0,05 & 0,1 & 0,1 & 0,02 & 0 & 0,15 & 0,42 & 0,070 \\
\hline $\begin{array}{l}\text { Treynoro ir Blacko } \\
\text { koeficientas }\end{array}$ & 0 & 0 & 0 & 0 & 0 & 0 & 0 & 0,000 \\
\hline Fondo turtas, mln. LT & 0,05 & 0,1 & 0,1 & 0,1 & 0,05 & 0,1 & 0,5 & 0,083 \\
\hline $\begin{array}{l}\text { Fondo investicinių vienetų } \\
\text { skaičius tūkst. }\end{array}$ & 0,05 & 0 & 0 & 0,01 & 0 & 0,05 & 0,11 & 0,018 \\
\hline Valdymo mokesčiai, \% & 0,1 & 0,15 & 0,15 & 0,1 & 0,1 & 0,2 & 0,8 & 0,133 \\
\hline Iš viso & 1 & 1 & 1 & 1 & 1 & 1 & 6 & 1 \\
\hline
\end{tabular}

Šaltinis: autorių skaičiavimai

Iš pateiktų duomenų (4 lentelè) matyti, kad, ekspertų nuomone, svarbiausi investicinių fondų veiklos efektyvumo vertinimo rodikliai yra Šarpo rodiklis, vidutinis investicinio vieneto vertès pokyčio standartinis nuokrypis, valdymo mokesčiai, investicijų grąža, investicinio vieneto vertès pokytis bei Alfa rodiklis. Mažiausiai reikšmingi Treynoro ir Blacko metodas, kuriam ekspertai priskyrẻ nulinị reikšmingumo laipsnị, taip pat fondo investicinių vienetų skaičius bei koreliacijos koeficientas.

Ivertinus pateiktas apklaustų ekspertų nuomones, toliau galima pereiti prie pagrindinio analizès metodo - kriterijų reikšmių ir jų reikšmingumų sandaugų sumavimo SAW metodo. Šis metodas akivaizdžiausiai apibūdina daugiakriterinio vertinimo prasmę (Žvirblis et al., 2008; Podvezko ir Ginevičius, 2008b). Norint tęsti skaičiavimus, buvo transformuoti ir normalizuoti duomenys ( 5 lentelè). Kadangi 3 lenteleje dauguma rodiklių turèjo neigiamas reikšmes, jos buvo perstumtos iki teigiamų, tai - vienas iš SAW metodo reikalavimų. Kitas žingsnis - nustatyti rodiklių tipą, ar jie yra maksimizuojantieji ar minimizuojantieji. Šiuo atveju minimizuojantieji rodikliai yra valdymo mokesčiai ir standartinis nuokrypis, kuris ịvertina riziką. Kuo minimizuojančiųjų rodiklių reikšmės mažesnès, tuo fondo 
veikla efektyvesnè. Likę rodiklių tipai - maksimizuojantieji; šių rodiklių didesnè reikšmė taip pat teigiamai veikia fondo veiklos rezultatus. Remiantis SAW metodo reikalavimais, maksimizuojamos reikšmès pertvarkomos į minimizuojamas ir atvirkščiai. Skaičiavimai atlikti naudojantis formulèmis (Ginevičius, 2006)

$$
\begin{gathered}
\tilde{r}_{i j}=\frac{\min _{j} r_{i j}}{r_{i j}} \\
\tilde{r}_{i j}=\frac{r_{i j}}{\max _{j} r_{i j}}
\end{gathered}
$$

Paskutinis etapas, prieš pradedant skaičiavimus pasirinktu metodu, yra rodiklių normalizavimas, kuris atliktas pagal formulę (Podvezko ir Ginevičius, 2008a):

$$
\tilde{r}_{i j}=\frac{r_{i j}}{\sum_{j=1}^{n} r_{i j}}
$$

Ši formulè-naudojama, norint apdorotas ir pertvarkytas reikšmes normalizuoti taip, kad kiekvieno kriterijaus reikšmių suma būtų lygi vienetui.

Surangavus ir suderinus ekspertų pateiktas reikšmes bei transformavus ir normalizavus duomenis, galima tęsti tyrimą ir skaičiuoti $S_{j}$ rodiklį pagal formulę (Ginevičius, 2006):

$$
S_{j}=\sum_{i=1}^{m} \omega_{i} \tilde{r}_{i j}
$$

kuris yra j-tojo objekto pasvertų reikšmių suma. Šis rodiklis sujungia kiekvieno fondo reikšmių sumas ir ekspertų vertinimus ị vieną reikšmę, kuri parodo valdomo investicinio fondo veiklos efektyvumą analizuojamuoju laikotarpiu (2008-2012 m.). Prieš pateikiant apibendrintus investicinių fondų rezultatus, tikslinga apžvelgti bendrus svorių pasiskirstymus tarp

\begin{tabular}{|c|c|c|c|c|c|c|}
\hline $\begin{array}{c}\text { Fondai / } \\
\text { kriterijus }\end{array}$ & $\begin{array}{c}\text { Citadele } \\
\text { Baltijos jūros } \\
\text { valstybių } \\
\text { akcijų fondas }\end{array}$ & $\begin{array}{c}\text { DNB akcijų } \\
\text { fondų } \\
\text { fondas } \\
\end{array}$ & $\begin{array}{l}\text { SEB aktyviai } \\
\text { valdomas } \\
\text { fondy̨ } \\
\text { portfelis } 100 \\
\end{array}$ & $\begin{array}{c}\text { DNB } \\
\text { likvidumo } \\
\text { fondas } \\
\end{array}$ & $\begin{array}{l}\text { SEB aktyviai } \\
\text { valdomas } \\
\text { fonduc } \\
\text { portfelis } 60 \\
\end{array}$ & $\begin{array}{l}\text { Svorių } \\
\text { suma }\end{array}$ \\
\hline $\begin{array}{l}\text { Fondo turtas, } \\
\text { mln. Lt }\end{array}$ & 0,0039 & 0,0031 & 0,0276 & 0,0114 & 0,0374 & 0,08 \\
\hline $\begin{array}{l}\text { Fondo investicinių } \\
\text { vnt. sk. tūkst. }\end{array}$ & 0,00001 & 0,0009 & 0,0088 & 0,000002 & 0,0086 & 0,02 \\
\hline $\begin{array}{l}\text { Valdymo mokes- } \\
\text { čiai, \% }\end{array}$ & 0,0131 & 0,0209 & 0,0209 & 0,0436 & 0,0349 & 0,13 \\
\hline Beta rodiklis & 0,0133 & 0,0112 & 0,0127 & 0,0201 & 0,0126 & 0,07 \\
\hline Alfa rodiklis, \% & 0,0472 & 0,0196 & 0,0036 & 0,0174 & 0,0038 & 0,09 \\
\hline Šarpo rodiklis & 0,0482 & 0,0437 & 0,0442 & 0,0141 & 0,0332 & 0,18 \\
\hline $\begin{array}{l}\text { Treynoro ir Blacko } \\
\text { koeficientas }\end{array}$ & 0,0000 & 0,0000 & 0,0000 & 0,0000 & 0,0000 & 0 \\
\hline
\end{tabular}
kriterijų. Pateikti duomenys (5 lentelè) rodo bendrą pasirinktų kriterijų ịtaką fondo veiklos rezultatams.

5 lentelė. Normalizuotų rodiklių dydžių ir ekspertų svorių reikšmių apibendrinti rezultatai 


\begin{tabular}{|l|r|r|r|r|r|r|}
\hline $\begin{array}{l}\text { Koreliacijos koefi- } \\
\text { cientas }\end{array}$ & 0,0152 & 0,0149 & 0,0159 & 0,0048 & 0,0159 & 0,07 \\
\hline $\begin{array}{l}\text { Standartinis nuo- } \\
\text { krypis, \% }\end{array}$ & 0,0027 & 0,0040 & 0,0028 & 0,1361 & 0,0044 & 0,15 \\
\hline $\begin{array}{l}\text { Grynoji investicijų } \\
\text { grąža, \% }\end{array}$ & 0,0038 & 0,0208 & 0,0132 & 0,0410 & 0,0246 & 0,10 \\
\hline $\begin{array}{l}\text { Investicinio viene- } \\
\text { to vertès pokytis, \% }\end{array}$ & 0,0277 & 0,0131 & 0,0044 & 0,0370 & 0,0177 & 0,10 \\
\hline
\end{tabular}

Šaltinis: autorių skaičiavimai

Apibendrinti duomenų svoriai rodo, kurie rodikliai labiausiai veikia fondų veiklą. Taigi, apskaičiuotos kriterijų sumos rodo, kad didžiausias pasiskirstymas yra tarp standartinio nuokrypio, Šarpo rodiklio, valdymo mokesčių, grąžos ir investicinio vieneto vertès pokyčio. Mažiausi svoriai yra fondo investicinių vienetų skaičiaus, koreliacijos koeficiento, Beta rodiklio ir Treynoro ir Blacko metodo, kuris fondų valdymui neturi jokios reikšmès. Atsižvelgiant ị tai, kad ekspertų nuomone, sudaryti rodiklių reikšmingumo koeficientai sutampa su bendrais rodiklių svorių rezultatais, galima daryti išvadą, kad analizė yra tikslinga ir suderinta.

Remiantis mokslinès literatūros analize ir finansinèse ataskaitose skelbiamais rodikliais, ị tyrimą ịtraukti pagrindiniai grąžos ir rizikos rodikliai. Rodikliai, atspindintys fondo charakteristikas, buvo pasirinkti, norint ištirti jų reikšmingumą fondo valdymui. Rezultatai parodè, kad valdymo mokesčiai yra tarp reikšmingiausių, tačiau kiti rodikliai, atsižvelgiant i gautas reikšmes, ịtakos neturi. Apklausti investicijų valdymo specialistai pabrèžè, kad fondo turto dydis iš esmès yra nereikšmingas rodiklis nepriklausomai nuo to, ar grynieji aktyvai sudaro $5 \mathrm{mln}$. Lt ar $5 \mathrm{mlrd}$. Lt. Didesnis nereiškia - efektyvesnis. Tačiau, kalbant apie Lietuvos rinką, šis rodiklis igauna prasmę, nes kai kurių fondų turtas gali tiek sumažèti, kad jų veikla bus nutraukiama. Todèl, vertinant gautus rezultatus (5 lentelè), matoma, kad fondo dydis pagal reikšmingumą yra tarp vidutiniškai reikšmingų rodiklių. Taigi, i analizę itrauktos fondo charakteristikos yra reikšmingos fondo veiklai.

Išanalizavus gautus duomenis pereinama prie paskutinio kompleksinio vertinimo etapo - gautų $S_{j}$ rezultatų analizès. Stulpelinèje diagramoje pavaizduoti duomenys (3 pav.), vaizduoja fondų rezultatų bendrą situaciją.

3 pav. Investicinių fondų veiklos rezultatai 2008-2012 m. laikotarpiu (kompleksinis įvertis)

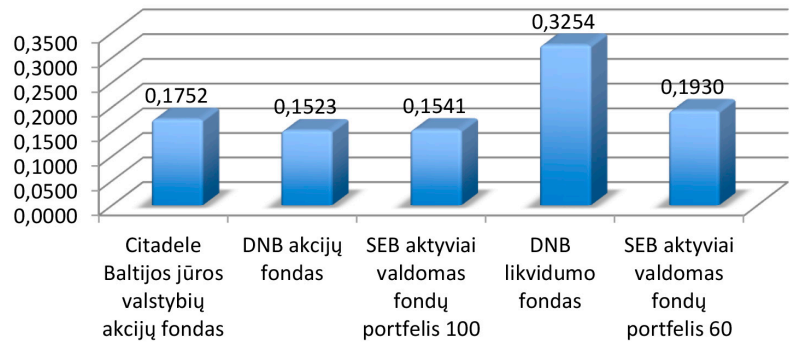

Šaltinis: sudaryta autorių 
Diagramoje pateikti duomenys rodo (3 pav.), kad analizuojamuoju laikotarpiu (20082012 m.) geriausiai veiklą vykdè DNB likvidumo fondas, kurio galutinei $\mathrm{S}_{\mathrm{j}}$ rodiklio reikšmei $(0,3254)$ didžiausią ịtaką darė maži valdymo mokesčiai ir mažiausias standartinis nuokrypis (rizika) lyginant su kitais fondais. Antrąją vietą užèmẻ SEB aktyviai valdomas fondų portfelis $60(0,1930)$, labiausiai šio fondo veiklai įtakos turejjo Šarpo rodiklis, fondo turtas ir valdymo mokesčiai. Reiktų paminèti, kad šio fondo valdymo mokesčiai yra dvigubai didesni nei DNB likvidumo fondo, tačiau fondo turtas yra ženkliai didesnis, jis turejo ịtakos ganėtinai geriems veiklos rezultatams. Paskutinèse vietose liko akcijų fondai. Trečiąją vietą pagal veiklos efektyvumą užèmė Citadelè Baltijos jūros valstybių fondas, kurio $S_{j}(0,1752)$ rodiklio reikšmei daugiausiai ịtakos turèjo Šarpo, Alfa rodikliai ir investicinio vieneto vertès pokytis, buvęs geresnis nei kitų, išskyrus DNB likvidumo fondą. Citadelè Baltijos jūros valstybių fondo Alfa rodiklis buvo pats aukščiausias iš visų analizuojamų fondų. Tai reiškia, kad fondą valdo valdytojai, sugebantys tinkamai pasirinkti riziką ir gauti didesnę grąžą, lyginant su kitomis rinkomis. Labai mažai skyrèsi likusieji fondai - SEB valdomas fondų portfelis 100 ir DNB akcijų fondas. Šių fondų veiklai daugiausiai ịtakos turejjo valdymo mokesčiai, Šarpo, Beta rodiklis, investicijų grąža bei valdomo turto dydis.

Taigi, galima teigti, kad pasirinkti investicinių fondų veiklos vertinimo rodikliai bei charakteristikos buvo tinkami pritaikyti daugiakriteriniam tyrimui. Kompleksinis vertinimas parode், kad efektyviausiai savo veiklą vykdè pinigų rinkos fondas - DNB likvidumo ir SEB aktyviai valdomas fondų portfelis 60 .

\section{Išvados}

Apibendrinant mokslineje literatūroje analizuojamus fondų vertinimo rodiklius ir metodus, teigtina, kad, taikant egzistuojančius metodus, padedančius įvertinti investicinių fondų veiklą, galima apskaičiuoti fondo pelningumą, rizikos laipsnị, valdytojo sugebejjimus, palyginti fondo veiklą su kitomis rinkomis. Tačiau nagrinėti rodikliai tik iš dalies leidžia susidaryti bendrą nuomonę apie investicinio fondo veiklą. Kiekvienas analizuotas rodiklis bei metodas turi tam tikrų trūkumų, vieni labiau orientuoti ị fondo grąžą ir nieko nepasako apie fondo rizikos laipsnị, kiti padeda įvertinti riziką, tačiau negali palyginti skirtingų strategijų fondų. Todèl, remiantis analizuota moksline literatūra, buvo pasirinkti pagrindiniai rodikliai, padedantys įvertinti bendrą fondo veiklos rezultatą: investicinio vieneto vertès pokytis, investicijų grąža, standartinis nuokrypis, koreliacijos koeficientas, Šarpo, Alfa ir Beta rodikliai, Treynoro ir Blacko koeficientas, fondo turto dydis, fondo investicinių vienetų skaičius ir valdymo mokesčiai.

Sudarius investicinių fondų veiklos vertinimo modelį SAW, apimantị pagrindinius fondų veiklos vertinimo rodiklius bei charakteristikas, atliktas daugiakriterinis investicinių fondų veiklos vertinimas. Nustatyti ekspertų priskirti vertinamiems kriterijams reikšmingumo svoriai padejo apskaičiuoti vertinamų kriterijų svorius, reikšmes ir kiekvienam investiciniam fondui išvesti bendrą vertinimą.

Daugiakriterinis vertinimas parodè, kad geriausiai 2008-2012 m. laikotarpiu veiklą vykdè DNB likvidumo fondas (0,3254) ir SEB aktyviai valdomas fondų portfelis $60(0,1930)$. Vertinant akcijų fondus, efektyviausiai veiklą vykdė Citadelè Baltijos jūros valstybių fondas $(0,1752)$. Kiti du akcijų fondai savo veiklos rezultatais atsiliko nuo pastarojo. Taigi, sudarytas investicinių fondų veiklos vertinimo modelis padejjo ịvairiapusiškai ịvertinti Lietuvos investicinių fondų veiklos rezultatus 2008-2012 m. laikotarpiu. 


\section{Literatūra}

Artikis, G. P. (2003). Performance evaluation: A case study of the Greek balanced mutual funds. Managerial finance, 29(9): 1-8.

Barras, L., Scaillet, O., and Wermers, R. (2010). False discoveries in mutual fund performance: Measuring luck in estimated alphas. The journal of finance, 65(1): 179-216.

Basu, D., and Chawla, D. (2012). An empirical test of the arbitrage pricing theory - The case of Indian stock market. Global bussines review, 13(3): 421-432.

Conover, M. C., and Friday, H. S. (2000). An analyses of cross section of returns for EREIT is using a varying - risk Beta model. Real estate economics, 28(1): 141-163.

Cuthberston, K., Nitzsche, D., and O'Sulivan, N. (2006). Mutual fund performance. Retrieved May 15, 2012 from http://papers.ssrn.com/sol3/papers.cfm?abstract_id=955807

Dzikevičius, A. (2004). Vertinimo, koreguoto pagal riziką, metodikų palyginamoji analizè. Socialiniai mokslai LŽŪU: mokslo darbai, 64(17): 97-103.

Elton, E. J., Gruber, M. J., Das, S., and Hlavka, M. (1993). Efficiency with costly informatikon: a reinterpretation of widence from managed portfolios. The review of financial studies, 6(1): 1-22.

Gavrilova, I. (2011). Lietuvos investicinių fondų veiklos vertinimas, atsižvelgiant ì riziką ir savalaikiškumą. Lietuvos ateitis: mokslo darbai, 3(4): 5-12.

Ginevičius, R. (2006). Daugiakriterinio vertinimo rodiklių svorių nustatymas, remiantis jų tarpusavio sąveika. Verslas teorija ir praktika: mokslo darbai, 7(1): 3-13.

Ginevičius, R., ir Podvezko, V. (2008a). Daugiakriterinio vertinimo būdų suderinamumas. Verslas teorija ir praktika: mokslo darbai, 9(1): 73-80.

Ginevičius, R. ir Podvezko, V. (2008b). Daugiakriterinio vertinimo taikymo galimybès kiekybiniam socialinių reiškinių vertinimui. Verslas teorija ir praktika: mokslo darbai, 9(2): 81-87.

Grinblatt, M., and Titman, S. (1994). A Study of Monthly Mutual Fund Returns and Performance Evaluation Techniques. Journal of financial and quantitative analysis, 29(3): 419-444.

Jasienè, M., ir Kočiūnaitè, D. (2007). Investicijų grąžos ịvertinimo atsižvelgiant ị riziką problema ir jos sprendimo galimybè. Ekonomika, 79(1): 64-76.

Lietuvos Respublikos Seimas. (2012) Lietuvos Respublikos kolektyvinio investavimo subjektų ístatymas [žiūrèta 2013-05-10], http://www3.lrs.lt/pls/inter3/oldsearch.preps2?a=428677\&b=

Lileikienè, A., ir Dauginyte, D. (2009). Investicinio portfelio valdymas: investicinès grąžos ir rizikos subalansavimas. Vadyba: mokslo darbai, 14(1): 15-27.

Markowitz, H. M. (1952). Portfolio selection. The journal of finance, 7(1): 77-91.

Markowitz, H. M. (1999). The early history of portfolio theory 1600-1960. Financial Analysts Journal, 55(4): 5-16.

Nielsen, L. T., and Vassalou, M. (2004). Sharpe ratios and alphas in continous time. Journal of fiancial and quantitative analysis, 39(1): 103-114.

Plakys, M. (2011). Tarptautiniai socialiai atsakingi investiciniai fondai. Mokslas - Lietuvos ateitis: mokslo darbai, 1(3): 56-60.

Pranulis, V.P., ir Dikčius, V. (2012). Rinkodaros tyrimai: teorija ir praktika. Vilnius: VU leidykla.

Sakalauskas, V. (2003). Investicijų rinkos vertinimas Lietuvos vertybinių popierių rinkoje. Informacijos mokslai: mokslo darbai, 27(1): 121-130.

Segejeva, J. (2011) Hierarchiškai struktūrizuotų procesų kompleksinis vertinimas. VGTU 14-osios Lietuvos jaunuju mokslininku konferencijos "Mokslas - Lietuvos ateitis“ 2011 metu temines konferencijos straipsnių rinkinys [žiūrèta 2013-05-10], http://dspace.vgtu.lt/bitstream/1/730/1/ Sergejeva.pdf

Stankevičienė, J., ir Bernatavičienė, A. (2012). Daugiakriterinis Lietuvos investicinių fondų veiklos efektyvumo vertinimas. Verslo ir teisés aktualijos: mokslo darbai, 7(2): 404-422.

Stanevičienè, J., ir Gavrilova, I. (2012). Lietuvos investicinių fondų vertinimas taikant kompleksinio vertinimo modeli. Verslas: teorija ir praktika: mokslo darbai, 13(1): 94-106.

Thanou, E. (2008). Mutual fund evaluation during up and down market conditions: the case of Greek equity mutual funds. Internatinal research journal of finance and marketing, 13: 84-93. 
Valentinavičius, S. (2010). Investiciju valdymas, teoriniai ir praktiniai aspektai. Vilniaus: VU leidykla. Žvirblis, A., Mačerisnkienė I., ir Buračas, A. (2008). İmonių konkurentų potencialo vertinimo principai ir baziniai modeliai. Intelektine ekonomika: mokslo darbai, 1(3): 82-92.

Žvirblis, A., ir Rimkevičiūte, V. (2012). Lietuvos investicinių fondų rodiklių ir makroveiksnių vertinimas. Socialiniu mokslu studijos: mokslo darbai, 4(1): 111-123.

\title{
INTEGRATED EVALUATION OF MUTUAL FUNDS PERFORMANCE
}

\author{
Daiva JUREVIČIENĖ \\ Gitana BAPKAUSKAITÉ \\ Mykolas Romeris University, Lithuania
}

\begin{abstract}
This paper analyzes evaluation methods of mutual funds performance, return and risk characteristics. Appropriate ratios are computed based on annual financial reports of investment funds and a model is made with an aim to evaluate financial situation of each investment fund separately considering assessments made by selected experts. The experts defined criteria and put certain significance weights and value estimations. The assessment of activities of the largest investment funds in terms of assets and participants, operating in 2008-2012 in Lithuania, is accomplished applying SAW assessment method.
\end{abstract}

Keywords: mutual fund returns, risk, SAW method, expert survey, diversification. 